\title{
Studying the Elimination Pattern of Caprine Arthritis Encephalitis Virus in the Milk of Infected Females
}

\author{
Natália Carrillo Gaeta', Marjorie Yumi Hasegawa', Bruno Leonardo Mendonça Ribeiro', \\ Ana Lisa Gomes'2, Roberto Soares Castro² \& Lilian Gregory'
}

\begin{abstract}
Background: Small ruminants can be infected by lentiviruses, such as Maedi-Visna Virus (MVV) and Caprine ArthritisEncephalitis Virus (CAEV). The main route of transmission is via ingestion of contaminated colostrum and milk although vertical transmission can occur. Recently, several studies for molecular detection of CAEV in milk, using conventional PCR and real-time PCR are being carried out. Considering the elimination of CAEV through the milk of infected animals and the importance of this virus in the goat production, the aim of this study was to evaluate the elimination pattern of CAEV in milk, evaluating the frequency and the concentration eliminated during the lactation.

Materials, Methods \& Results: A cohort of four negative females for CAEV was inseminated with semen experimentally infected with CAEV-Cork strain. They were located in stalls at the Hospital of Ruminants from School of Veterinary Medicine and Animal Science from University of São Paulo, Brazil. Goats received coast-cross hay, pellet feeding, mineral salt and water ad libitum. All females were observed every day during pregnancy. After lambing, kids received warm bovine colostrum and bovine milk powder during two months. Forty milk samples were collected at five-day interval during two months. A mixture of five milliliters from each teat was obtained and cDNA extraction was performed using DNA Mini Kit. Initially, real-time PCR was performed using an endogenous control for research of the constitutive gene (12S) for goats. Using positive samples in the first reaction, another reaction was performed using specific primers for lentiviruses based on the gag gene (conserved in retroviruses). In order to compare the results, nested-PCR was performed. After realtime PCR, cDNA was detected in samples from one female, corresponding to the day of calving, $14^{\text {th }}, 20^{\text {th }}, 25^{\text {th }}, 35^{\text {th }}$ and $40^{\text {th }}$ day postpartum $(15 \% ; 6 / 40)$. The absence of amplified cDNA in thirty days postpartum, as well as in the final twenty days of lactation, was observed. Sample corresponding to the $7^{\text {th }}$ day postpartum was not obtained. The virus concentration throughout lactation grew up until forty days postpartum. After this period, there was no cDNA amplification. In Nested PCR, positive results were detected in samples corresponding to the day of calving, $15^{\text {th }}$ days, $20^{\text {th }}$ days and $30^{\text {th }}$ days postpartum, only.

Discussion: cDNA was detected in samples from one positive female, during forty days postpartum, but not on the $30^{\text {th }}$. On the other hand, amplified cDNA was observed on $30^{\text {th }}$ day by nested-PCR. In this case, a false negative result was observed after real-time PCR, probably because sample corresponding to $30^{\text {th }}$ days may not have been properly homogenized, so that the fraction used in real-time PCR was not representative. A higher number of positive samples were expected due to the higher sensitivity of the technique used. The low viral concentration in the milk due to high antibody titers, for example, leaded to a small number of cells containing the agent, reducing the possibility of detection. cDNA was not detected in any sample from three infected females. A possible false-positive serological reaction or the very low viral concentration in milk samples could explain the negative results, although some animals might be infected by a strain that could not be recognized by PCR.
\end{abstract}

Keywords: CAEV, small ruminant, milk, virology, Real-Time PCR. 


\section{INTRODUCTION}

According to FAO (2014), there are 875 million of goats worldwide. Brazilian flock comprises approximately 14 million of animals, stating Brazil as the $18^{\circ}$ in the exportation ranking [12].

Small ruminants can be infected by lentiviruses, such as Maedi-Visna Virus (MVV) and Caprine ArthritisEncephalitis Virus (CAEV) [1] .Caprine arthritis encephalitis (CAE) is an infection that affects multiple systems such as locomotor, reproductive, respiratory and nervous, with clinical signs such as weight loss, arthritis, encephalitis and mastitis [14]. It is characterized by high prevalence of seropositive and generally low morbidity. The main route of transmission is via ingestion of contaminated colostrum and milk [1,5], although vertical transmission can occur [9]. The diagnosis of CAEV can be accomplished by serological and molecular reactions. The techniques widely used are Agarose Gel Immunodiffusion (AGID) and Enzyme-Linked Immunosorbent Assay (ELISA), recommended by the World Organization for Animal Health (OIE) and adopted by the Ministry of Agriculture (MAPA), in Brazil. Recently, several studies for molecular detection of CAEV in milk, using conventional PCR and real-time PCR (qPCR) are being carried out [7,10,15] because of their high sensitivity and specificity, besides the rapid results. Considering the elimination of CAEV through the milk of infected animals [7] and the importance of this virus in the goat production, the aim of this study was to evaluate the elimination pattern of CAEV in milk, assessing the frequency and the concentration eliminated during the lactation of experimentally infected goats.

\section{MATERIALS AND METHODS}

\section{Animals, feeding and facilities}

A cohort of four negative females for CAEV was inseminated with semen experimentally infected with CAEV-Cork strain. They were located in stalls at the Hospital of Ruminants from School of Veterinary Medicine and Animal Science from University of São Paulo, Brazil. Goats received coast-cross hay, pellet feeding, mineral salt and water ad libitum. All females were observed every day during pregnancy. After lambing, kids received warm bovine colostrum and bovine milk powder during two months.

Milk collection

Forty milk samples were collected in a five day interval during two months. Ten milliliters of milk of each teat were placed in Falcon tubes and frozen at $-4^{\circ}$ $\mathrm{C}$ until processing.

\section{DNA extraction}

Before cDNA extraction, a mixture of five milliliters from each teat (totaling $10 \mathrm{~mL}$ ) was added in a Falcon tube. Samples were centrifuged at $1500 \times \mathrm{x}$ at $4^{\circ} \mathrm{C}$ for $10 \mathrm{~min}$. Fat and supernatant were discarded and pellet resuspended in one mililiter of PBS solution. The suspension was transferred to another tube and nine milliliters of PBS was added. The suspension was centrifuged at $1500 \mathrm{~g}$ at $4^{\circ} \mathrm{C}$ for $10 \mathrm{~min}$. The supernatant was discarded and the pellet resuspended in $200 \mu \mathrm{L}$ of PBS. Samples were conditioned at $-20^{\circ} \mathrm{C}$. cDNA extraction was performed using DNA Mini Kit (QIAmp) ${ }^{1}$ according Brinkhof et al. [2].

\section{Real-Time PCR}

Real-Time PCR (qPCR) was performed on Applied Biosystems 7500 Thermocycler ${ }^{2}$ [15]. All samples were analyzed in duplicate. Initially, the study of endogenous control for research of the constitutive gene (12S) for goats (called housekeeping), was performed using the following oligonucleotides - 12S-R 5'-TGAGTT-TCGGGCTGTTGCCG-3' and 12S-F 5'-CGAGCCACCGCGGTCATACG-3'. Real-time PCR reaction were prepared in $25 \mu \mathrm{L}$ total volumes, containing $12.5 \mu \mathrm{L}$ of master mix (Syber Green) 1,20 $\mathrm{mM}$ of each primer, $6.5 \mu \mathrm{L} \mathrm{dH} 2 \mathrm{O}$ and $2 \mu \mathrm{L}$ of sample DNA. Using positive samples for the first reaction, another reaction was performed using primers for lentiviruses - CF2 5'-GTTCCAGCAACTGCAAACAGTAGCAATG-3 'and CR2 5'-ACCTTTCTGCTTCTTCATTTAATTTCCC-3', which were built based on the gag gene (conserved in retroviruses) [11]. The latter reaction was performed using the same conditions as described before.

In all reactions, a negative control consisting of the reagents excepting the DNA sample was used. The positive control was a CAEV cDNA ( $15 \mathrm{pmol} /$ $\mathrm{uL}$ ) kindly provided by Laboratory of Animal Virology from the Federal Rural University of Pernambuco. Both controls were used in duplicate. The standard curve was prepared using the cDNA diluted from 1:1 until 1:1000.

\section{Nested-PCR}

Nested PCR was performed in Thermal Cycler (Eppendorf) ${ }^{3}$ using positives samples detected by Real-time PCR. All reactions were prepared in $50 \mu \mathrm{L}$ 
total volumes, containing: 10X PCR buffer $(200 \mathrm{mM}$ Tris- $\mathrm{HCl}$ (pH 8.4), $500 \mathrm{mM} \mathrm{KCl,} 50 \mathrm{mM} \mathrm{MgCl} 2,10$ $\mu \mathrm{M}$ of each dATP, dGTP, dTTP and dCTP, $10 \mu \mathrm{M}$ of each primer, and $1 \mathrm{U}$ Taq Polymerase. After $5 \mathrm{~min}$ initial denaturation at $95^{\circ} \mathrm{C}, 35$ cycles were performed with the following parameters: $95^{\circ} \mathrm{C}$ for $45 \mathrm{~s}, 55^{\circ} \mathrm{C}$ for $45 \mathrm{~s}$ and $72^{\circ} \mathrm{C}$ for $45 \mathrm{~s}$. The final extension was performed at $72^{\circ} \mathrm{C}$ for $8 \mathrm{~min}$. Fragments were analyzed by electrophoresis in a $1.2 \%$ agarose gel in TBE buffer $(0.09$ $\mathrm{M}$ Tris-Borate and 0.002 M EDTA, pH 8.0), stained with ethidium bromide. Bands were analyzed by UV light and photographed using a photo documenter $\left(\operatorname{BioRad}^{\circledR}\right)^{4}$.

\section{RESULTS}

After Real-Time PCR, cDNA was detected in samples from one female, corresponding to the day of calving, $14^{\text {th }}, 20^{\text {th }}, 25^{\text {th }}, 35^{\text {th }}$ and $40^{\text {th }}$ day postpartum $(15 \%=6 / 40)$. The absence of amplified cDNA in thirty days postpartum, as well as in the final twenty days of lactation, was observed. Sample corresponding to the s7th day postpartum was not obtained. The virus concentration throughout lactation grew up until forty days postpartum. After this period, there was no cDNA amplification (Figure 1).

In Nested PCR, positive results were detected in samples corresponding to the day of calving, $15^{\text {th }}$ days, $20^{\text {th }}$ days and $30^{\text {th }}$ days postpartum, only.

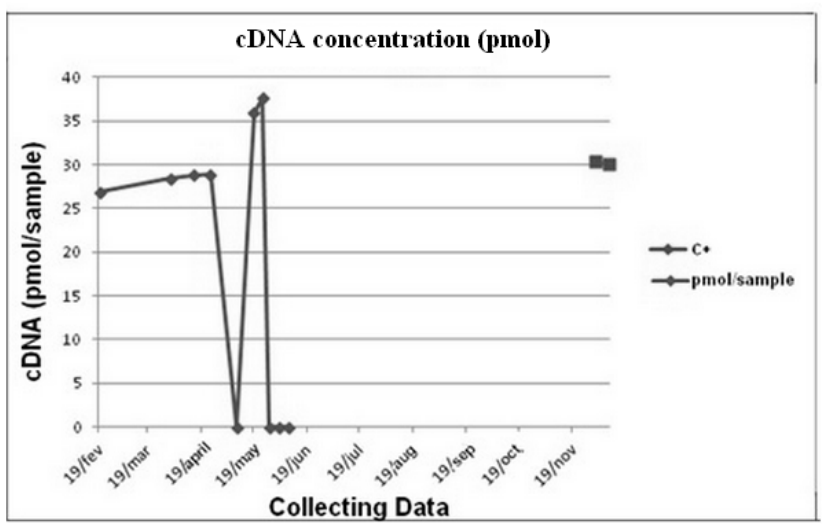

Figure 1. Evolution of cDNA (pmol) volume during lactation of healthy females inseminated with infected semen.

\section{DISCUSSION}

cDNA was detected in samples from one positive female, during forty days postpartum, but not on the $30^{\text {th }}$. On the other hand, amplified cDNA was observed on $30^{\text {th }}$ day by nested-PCR. In this case, a false negative result was observed after real-time PCR, probably because sample corresponding to $30^{\text {th }}$ days may not have been properly homogenized, so that the fraction used in real-time PCR was not representative. Despite the absence of the sample corresponding to the $7^{\text {th }}$ days postpartum, the trend of the results suggests high probability that this sample was also positive.

In the present study, the number of positive samples was higher compared to the results described by Silva et al. [15], which detected positive samples by realtime PCR in only $6 \%$ (11/179). However, the number of positive samples in the present study was lower compared to those described by Leroux et al. [10], which detected $100 \%$ (28/28) of positives by real-time PCR. Similarly, De Regge et al. [4] detected $61 \%$ of positives by realtime PCR after re-test positive samples on ELISA-test. A higher number of positive samples were expected due to the higher sensitivity of the technique used. The low viral concentration in the milk due to a high antibody titers, for example, leaded to a small number of cells containing the agent, reducing the possibility of detection [14].

cDNA was not detected in any sample from three infected females. Similarly, De Regge et al. [4] did not detected amplification in 39\% (09/23) by realtime PCR using positive samples on ELISA-test. A possible false-positive serological reaction or the very low viral concentration in milk samples could explain the negative results, although some animals might be infected by a strain that could not be recognized by PCR. Although the technique identifies animals carrying the lentiviruses before seroconversion, it is reported that PCR has become less sensitive when compared to serological tests after viremia, and the combination of them are recommended for diagnosis and disease control [3].

In nested PCR, cDNA was obtained in samples corresponding to the day of calving, $15^{\text {th }}, 20^{\text {th }}$ and $30^{\text {th }}$ days postpartum $(10 \%=4 / 40)$. Similarly, Gregory et al. [8], detected only $6 \%$ of positivity using nested-PCR. On the other hand, Gregory et al. [7] detected 22.2\% of positive milk samples using the same technique.

Brinkhof et al. [2] reported that the detection of cDNA in milk samples may indicate a viral infection in the mammary gland, and it agrees with the transmission by contaminated colostrum and milk hypothesis [13]. The infection of goats by ingesting infected colostrum and milk has been described elsewhere $[1,5,6,9,15]$. Therefore, feeding kids with milk of infected females should be avoided. 
N.C. Gaeta, M.Y. Hasegawa, B.L.M. Ribeiro, et al. 2016. Studying the Elimination Pattern of Caprine Arthritis Encephalitis Virus

MANUFACTURERS

${ }^{1}$ Qiagen. Valencia, CA, USA.

${ }^{2}$ Life Technologies. Carlsbad, CA, USA.

${ }^{3}$ Eppendorf. Hamburgo, Germany.

${ }^{4}$ Thermo Scientific. Waltham, MA, USA.

Funding. São Paulo Research Foundation (FAPESP) [Process $\left.n^{\circ} 2012 / 19324-8\right]$.

Acknowledgements. We are greatful to Faculdade de Medicina Veterinária e Zootecnia (FMVZ) - Universidade de São Paulo
(USP) for the structural support and all students for helping us during the experiment

Ethical approval. The experiment was approved and performed under the guidelines of Ethics Committee for Animal Use of Faculdade de Medicina Veterinária e Zootecnia from Universidade de São Paulo.

Declaration of interest. The authors report no conflicts of interest. The authors alone are responsible for the content of the paper.

\section{REFERENCES}

1 Blacklaws B.A., Berriatua E., Torsteinsdottir S., Watt N.J., de Andres D., Klein D. \& Harkiss G.D. 2004. Transmission of small ruminant lentiviruses. Veterinary Microbiology. 101(3): 199-208.

2 Brinkhof J.M.A., Houwers D.J., Moll L., Dercksen D. \& van Maanen C. 2010. Diagnostic performance of ELISA and PCR in identifying SRLV-infected sheep and goats using serum, plasma and milk samples and in early detection of infection in dairy flocks through bulk milk testing. Veterinary Microbiology. 142(3-4): 193-198.

3 De Andrés D., Klein D., Watt N.J., Berriatua E., Torsteinsdottir S., Blacklaws B.A. \& Harkiss G.D. 2005. Diagnostic tests for small ruminant lentiviruses. Veterinary Microbiology. 107(1-2): 49-62.

4 De Regge N. \& Cay B. 2013. Development, validation and evaluation of added diagnostic value of a q(RT)-PCR for the detection of genotype A strains of small ruminant lentiviruses. Journal of Virology. 194(1-2): 250-257.

5 East N.E., Rowe J.D., Dahlberg J.E., Theilen G.H. \& Pederson N.C. 1993. Modes of transmission of caprine arthritis-encephalitis virus infection. Small Ruminant Research. 10(3): 251-262.

6 Ellis T.M., Robinson W.F. \& Wilcox G.E. 1988. The pathology and aetiology of lung lesions in goats infected with caprine arthritis-encephalitis virus. Australian Veterinary Journal. 65(3): 69-73.

7 Gregory L., Lara M.C.C.S.H., Villalobos E.M.C., Hasegawa M.Y., Castro R.S., Rodrigues J.N.M., Araújo J., Keller L.W. \& Durigon E.L. 2009. Detecção do vírus da Artrite Encefalite Caprina em amostras de leite de cabras pela reação em cadeia da polimerase (PCR) e Nested-PCR. ARS Veterinaria. 25(3): 142-146.

8 Gregory L., Lara M.C.C.S.H., Hasegawa M.Y., Castro R.S., Fatini L.C., Gaeta N.C., Rodrigues J.N.M., Araújo J., Keller L.W. \& Durigon E.L. 2011. Detecção do vírus da Artrite Encefalite Caprina em pulmão, glândula mamária, cérebro e líquido sinovial de cabras naturalmente infectadas pela técnica de nested-PCR. Medicina Veterinária. 5(1): 7-11.

9 Lara M.C.C.S.H. 2007. Artrite-encefalite dos caprinos - Aspectos clínicos e epidemiológicos. 247f. São Paulo, SP. Tese (Doutorado em Ciências Veterinárias) - Programa de Pós-graduação em Clínica Veterinária, Faculdade de Medicina Veterinária e Zootecnia, Universidade de São Paulo.

10 Leroux C., Lerondelle C., Chastang J. \& Mornex J.F. 1997. RT-PCR of lentiviruses in milk or mammary secretions of sheep or goats from infected flocks. Veterinary Research. 28(33): 115-121.

11 Lima P.P., Rocha M.A., Stancek D., Gouveia A.M.G. \& Oliveira G.D.R. 2004. Vírus da artrite encefalite caprina: isolamento e caracterização de parte do gene gag. Arquivo Brasileiro de Medicina Veterinária e Zootecnia. 56(2): 135-142.

12 Organização das Naçoes Unidas para Agricultura e Alimentação. 2014. Fonte: <https://www.fao.org.br/.>[Accessed October 2015].

13 Peretz G., Asso J. \& Devillechaise P. 1993. Le C.E.A.V: Revue des connaissances actuelles et conséquences pratiques. Revue de Médicine Vétérinaire. 144(2): 93-98.

14 Santos L.M.M., Nascimento E.R., Meirelles K.C., Castro R.S. \& Pereira V.L.A. 2009. Detecção da infecção pelo vírus da Artrite Encefalite Caprina (CAEV) pela imunodifusão em gel de agarose (IDGA) e reação em cadeia da polimerase (PCR). In: Anais do VIII Congresso Brasileiro de Buiatria (Belo Horizonte, Brasil).p.557.

15 Silva M.L.C.R., Castro R.S., Maia R.C., Nascimento S.A., Gomes A.L.V. \& Azevedo S.A. 2013. Lentivírus em caprinos leiteiros do semiárido paraibano: prevalência de anticorpos, fatores de risco e detecção molecular. Pesquisa Veterinária Brasileira. 33(4): 453-458. 